Cotes received twelve complimentary copies, but probably he refused all other recompense. A third edition appeared in 1726, but this contained only minor alterations; it was edited by Henry Pemberton, who received $£ 200$ from Newton for his work. Pemberton is also reputed to have received $£ 3,000$ for his "A View of Sir Isaac Newton's Philosophy", which was published by subscription; the subscribers numbered some 2,400, including peers of the realm, most of the bishops, and other notables including Alexander Pope and Edward Gibbon, a remarkable tribute to the esteem in which Newton was held. Collected editions of Newton's work were published in Lausanne and Geneva in 1744 in three volumes, and in London during 1779-85, though neither is complete. It is to be hoped that steps will be taken to produce a complete edition of the works of Britain's most distinguished natural philosopher.

\section{Sir John Russell, F.R.S.}

ON September 30, 1943, Sir John Russell will retire from the directorship of the Rothamsted Experimental Station, which he has held since 1912, when he succeeded the late Sir Daniel Hall. During 1907-12 he was Goldsmiths' Company soil chemist at Rothamsted. In these thirty-five years of service Sir John has been associated with striking advances in agricultural science. An early achievement was the evolution of a method-then conveniently described as partial sterilization-for restoring the fertility of rich, but 'sick', soils such as tomato and cucumber beds. A sub-station of Rothamsted was established at Cheshunt, in the centre of the glass-house industry, to deal with this and related problems ; its work was so successful that it quickly became an independent research institute. During the War of 1914-18 Sir John was technical adviser to the Food Production Department. Shortly after the War, the agricultural research and advisory organization was greatly expanded by the Government and, in common with other institutes, Rothamsted enlarged its staff and its programme of research to include plant pathology and entomology as well as its traditional subjects of soil science and crop growth. Important scientific advances were made in all of these branches and Sir John attacked the double problem of testing them under varying soil conditions and agricultural systems, and of accelerating their absorption into farm practice. He increased the contacts of Rothamsted with agrioulturists and farmers' organizations until the objects and work of the Station became as well known in the countryside as among men of science. Striking proof of this was given in 1934, when the experimental fields were threatened with building developments : a public appeal was issued for funds to purchase the farm, and the amount

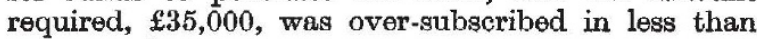
two months,

A further development, sponsored by Sir John, was the extension of Rothamsted's activities to overseas agricultural problems. This work began in 1923 when he was invited to the Sudan to advise on agricultural developments and scientific activities. Since that date he has made extensive visits to the Dominions, India and a number of the Colonies, as well as to many foreign eountries, either by direct invitation from their Governments, or as the British Government delegate. He took a leading part in the Imperial Agricultural Research Conference of 1927, as a result of which the Imperial Agricultural Ro- search Bureaux were set up, the one for Soil Science being located at Rothamsted under his direction. In pursuance of his policy of making widely known the scientific and practical results of agricultural research, Sir John has written a number of authoritative books on agricultural science and practice. The best known is "Soil Conditions and Plant Growth", which first appeared in 1912 and is now in its seventh edition. The successive editions contain their own record of the striking advances with which his name is associated. In recent years Sir John has done much to develop the international aspects of agricultural research. But for the War, Rothamsted would have celebrated its centenary in 1943 by an international gathering. This project has been submerged by the urgent war problems and the looming difficulties of post-war agricultural reconstruction in devastated Europe. In these problems Sir John is taking an active part. He serves as adviser to the Russian Branch of the Ministry of Information, and is a member of the Inter-Allied Government Committee on Post-War Requirements.

\section{Bicentenary of Scheele (1742-I786)}

ThE bicentenary of the birth of the Swedish chemist Carl Wilhelm Scheele, whose recently published manuscripts were reviewed in our columns on November 7, falls on December 19. His birthplace was Stralsund, in Pomerania, then a Swedish province, but he was trained as a pharmacist in Gothenburg. Here he remained until the age of twenty-three, studying the works of Stahl, Lemery, Kunckel and Neumann and for ever experimenting. From Gothenburg hewent to Malmo, then to Stockholmand Uppsala, where he met Gahn and secured the friendship of Bergmann. At last in 1775, at the age of thirty-three, he was officially appointed apothecary at the little town of Köping on the western shore of Lake Malar. His death took place at Köping on May 19, 1786, when he was only forty-three. Among a crowd of original discoveries those relating to chlorine, manganese and oxygen are the best known. His papers were printed mainly in the Transactions of the Royal Academy of Stockholm. Dr. Beddoes translated his "Chemical Essays" in $\mathbf{1 7 8 6}$ and a reprint of this was published in 1901. This was reviewed in Nature of November 7, 1901, the reviewer remarking then, "The strict fidelity to experiment, the rare sagacity, the sorupulous and minute observation and the extraordinary experimental skill combine to make Scheele a model for all time. When we add to this the pathos of his early struggles, the simplicity of his blameless life and the nobility of his untimely death, there can be no wonder that Scheele is reckoned a hero among chemists".

\section{University Students and Military Service}

IN the discussions in the House of Commons on December 9 and 10 on the National Service Bill, 1942, Mr. E. Bevin, Minister of Labour, pointed out that the measure was largely an administrative one to facilitate the calling up of young men of eighteen. The position of prospective university students was discussed by several members of the House. Mr. K. Lindsay remarked that the Bill meant the end of university life in Great Britain during the War, ex. cept for a few specialists. Mr. Harvey asked for an assurance that if an undergraduate's work was satisfactory he would be allowed to complete an academic year before being called up. Sir P. Harris said that 